\title{
Effect of Trichoderma on Growth and Sporangia Production of Phytophthora capsici
}

\author{
Estefanía Ramírez-Delgado ${ }^{1}$, José de J. Luna-Ruíz ${ }^{1}$, Onésimo Moreno-Rico ${ }^{2}$, Jesús D. C. Quiroz-Velásquesz ${ }^{3}$ \\ \& José L. Hernández-Mendoza ${ }^{3}$ \\ ${ }^{1}$ Centro de Ciencias Agropecuarias, Universidad Autónoma de Aguascalientes, Aguascalientes, México \\ ${ }^{2}$ Centro de Ciencias Básicas, Universidad Autónoma de Aguascalientes, Aguascalientes, México \\ ${ }^{3}$ Centro de Biotecnología Genómica, Instituto Politécnico Nacional, Reynosa, Tamaulipas, México \\ Correspondence: Jose de J. Luna-Ruiz, Centro de Ciencias Agropecuarias, Universidad Autónoma de \\ Aguascalientes, Av. Universidad 940, Cd. Universitaria, Aguascalientes, Ags. 20131, Mexico. Tel: \\ 1-52-449-9107400 ext. 8104. E-mail: joselunaruiz11@yahoo.com.mx
}

Received: January 23, 2018

Accepted: April 2, $2018 \quad$ Online Published: May 15, 2018

doi:10.5539/jas.v10n6p8

URL: https://doi.org/10.5539/jas.v10n6p8

\begin{abstract}
Phytophthora capsici is the main agent of chili pepper root rot, causing significant yield losses in commercial fields worldwide. Management of this plant pathogen has been difficult due to its ability to develop fungicide resistance, therefore biocontrol of $P$. capsici appears to be a promising alternative. In this study we evaluated the effects of three species of Trichoderma: T. harzianum (Th-7), T. koningiopsis (Tk NRRL50190) and T. asperellum (Ta NRRL50191) on two mexican isolates of P. capsici (RDP-1 and RDP-2) obtained from commercial pepper fields in Aguascalientes, Mexico. The ability to inhibit mycelia growth of $P$. capsici was tested with in vitro assays, followed by the quantification of sporangia after dual confrontations. All Trichoderma isolates inhibited the mycelia growth of the phytopathogen, but only Ta and Tk showed mycoparasitism. Sporangia production of P. capsici RDP-1 and RDP-2 was significantly reduced by Trichoderma isolates, compared to the non-confronted control, except for the Th-RDP-2 confrontation. Sporangia of RDP-1 significantly decreased by $95.6 \%, 81.3 \%$ and $78 \%$ after confrontations with $\mathrm{Tk}$, Ta and Th, respectively; and by $76 \%$ and $85.4 \%$ in RDP- 2 by Tk and Ta, respectively. The results suggest that Ta, Tk and Th could be used as potential biocontrol agents of Phytopthora root rot, however, further studies are necessary to test the in vivo protection of Ta, Tk and Th and their synergistic effects against Phytophthora root rot of chile peppers and other $P$. capsici susceptible solanaceous and cucurbitaceous crops such as tomatoes, squash, melons, and cucumbers.
\end{abstract}

Keywords: biocontrol, Phytophthora capsici, sporangia, Trichoderma

\section{Introduction}

The oomycete Phytophthora capsici is a highly destructive pathogen affecting mainly solanaceous and cucurbitaceous crops. In Mexico, $P$. capsici is the most devastating of the soil-borne pathogens that affect chili peppers (Robles-Yerena et al., 2010). It has the capability of infecting subterranean and aerial plant tissues, causing root, stem and fruit rot, and also leaf blight (Quesada-Ocampo \& Hausbeck, 2010). When favorable environmental conditions occur under rainfall or irrigation, $P$. capsici produces thousands of sporangia in free water, releasing 20 to 40 zoospores each. All zoospores have the potential to start a new infection (Granke et al., 2012).

If the conditions are favorable for disease development, fungicide application may not be sufficient to control this pathogen (Marín et al., 2014), because P. capsici is resistant to a variety of fungicides such as mefenoxam (Silva-Rojas et al., 2009; Foster \& Hausbeck, 2010), copper sulphate (Fernández-Pavía et al., 2004) azoxystrobin, metalaxyl and propamocarb (Pérez-Moreno et al., 2003). Therefore, new and more promising and sustainable alternatives are required such as genetic resistance and biological control. The biological control using antagonistic organisms is a valuable and more sustainable non-chemical tool, which has stimulated efforts to detect microorganisms with potential as biocontrol agents. Among the vast variety of microorganisms that have shown to suppress the growth of P. capsici, the most explored have been rizhobacteria (Jong-Hiu \& Sang-Dal, 
2010) and Trichoderma (Segarra et al., 2013; Jiang et al., 2016), both individually and combined for synergistic effects (Chemeltorit et al., 2016).

The beneficial effects of Trichoderma have been attributed to its capacity to antagonize pathogens like Phytophthora, due to a combination of antibiosis, mycoparasitism and competition for substrate and space (Bae et al., 2016). Antibiosis entails the production of compounds such as gliotoxin and viridina which have an antibiotic activity (Osorio-Hernández et al., 2011), and inhibit the development of other microorganisms. However, these metabolites inhibit the germination and root growth of mustard and other dicotiyledons in vitro, while in monocots their effect is minor (Bailey \& Lumsden, 1998). Other metabolites produced by Trichoderma are viridiol, which has an herbicide activity, and the variant 9-epi-viridiol wich has a cytotoxic effect (Phuwapraisisan et al., 2006).

Several species of microorganisms are commercially available as biocontrol agents against soil-borne pathogens, nevertheless, it has been reported that some of these products are not effective against $P$. capsici in tomato (Fernández-Herrera et al., 2007). Also, plants treated with Trichoderma spp. may not be protected against Phytophthora attacks because no mechanisms to inhibit zoospores is yet known (Harman, 2000).

Most investigations have been focused in demonstrating the effectiveness of various Trichoderma strains, especially under laboratory conditions in order tp elucidate the antagonistic mechanisms, and in most cases, the effects and responses of $P$. capsici during this interaction. The aim of this work was to evaluate the antagonistic effects of three species of Trichoderma (T. asperellum, T. koningiopsis and T. harzianum), on the in vitro mycelia growth and sporangia production of two $P$. capsici isolates from chile pepper.

\section{Materials and Methods}

\subsection{Strains}

The two $P$. capsici strains were isolated from infected roots of commercial chili pepper in Central Mexico, and maintained on V8 juice agar (V8-A) media. Morphological identification of $P$. capsici was based on Erwin and Ribeiro (1996). T. koningiopsis (Tk NRRL50190), and T. asperellum (Ta NRRL50191) were provided by the Experimental Biotechnology Lab, Centro de Biotecnologia Genomica, Instituto Politecnico Nacional (CBG-IPN) and T. harzianum (Th-7) was provided by the Microbiology Lab, Universidad Autonoma de Aguascalientes (UAA), Mexico. The Trichoderma and P. capsici strains were maintained on PDA and V8-A media, respectively.

\subsection{DNA Isolation and Molecular Identification of P. capsici}

Mycelia of the $P$. capsici isolates were grown in $50 \mathrm{ml}$ of potato dextrose broth for $72 \mathrm{~h}$ in a shaker at $200 \mathrm{rpm}$ under $25^{\circ} \mathrm{C}$, followed by centrifugation at $3500 \mathrm{rpm}$ for $10 \mathrm{~min}$. The supernatant was discarded and the mycelia biomass was frozen at $-20^{\circ} \mathrm{C}$ until the analysis. Genomic DNA was extracted using a chloroform-octanol (24:1) procedure adapted from the protocol of Reader and Broda (1985). DNA was resuspended in nuclease-free water.

PCR reactions were conducted on a thermocycler (GeneAmp® PCR System 9600 PE Appled Biosystem); the amplifications were performed using three specific primers (PHYTO-primers): one Forward (5'-CTTTCCACGTGAACCGTWTC-3'), and two Reverse primers (5'-CAAAATGGATCGACCCCTCG-3' and 5'-CCAAATGGATCGACCCTCG -3'). A volume of $25 \mu \mathrm{l}$ was prepared by mixing $1 \mu 1$ of the DNA with $2.4 \mu 1$ of Buffer 10X (final concentration $1 \mathrm{X}$ ), $0.75 \mu \mathrm{l}$ of magnesium chloride of $50 \mathrm{mM}, 1 \mu \mathrm{l}$ of each primer $(5 \mu \mathrm{M}), 0.2$ $\mu \mathrm{l}$ of dNTPs $10 \mathrm{mM}, 0.2 \mu \mathrm{l}$ of Taq polymerase $5 \mathrm{U} / \mu \mathrm{l}$, and adjusted to a final volume of $50 \mu \mathrm{l}$ with Milli-Q sterile water. The PCR conditions were as follows: denaturation at $95{ }^{\circ} \mathrm{C}$ for $2 \mathrm{~min}$, followed by 30 cycles of $30 \mathrm{~s}$ at $95{ }^{\circ} \mathrm{C}, 30 \mathrm{~s}$ at $59{ }^{\circ} \mathrm{C}$, and $60 \mathrm{~s}$ at $72{ }^{\circ} \mathrm{C}$, with a final extension time of $5 \mathrm{~min}$ at $72{ }^{\circ} \mathrm{C}$. Electrophoresis analysis was applied to PCR products in a $1 \%$ agarose gel at $85 \mathrm{~V}$ during $1 \mathrm{~h}$, with Syber Gold and Orange as stainers. The amplified products were visualized in a Bio-Rad Molecular Imager ${ }^{\circledR}$ Gel Doc ${ }^{\mathrm{TM}}$ XR. The sequencing was executed by automated DNA sequencing (ABI Prism $\left.{ }^{\circledR}\right)$ using Big Dye ${ }^{\circledR}$ technology. Sequence alignments and corrections were done using the CLC Sequence Viewer program version 7. Product sequences were compared with similar sequences in the GenBank using BLASTn.

\subsection{In vitro Assays}

Antagonistic activity of Trichoderma species against $P$. capsici strains were determined by dual culture in V8-A. A $5 \mathrm{~mm}$ diameter disc of active mycelia from each antagonistic species ( $\mathrm{Tk}$, Ta or $\mathrm{Th}$ ) was placed opposite to each isolate of $P$. capsici mycelia disc on a Petri plate. All dual culture plates were incubated in darkness at $30{ }^{\circ} \mathrm{C}$. Individual plates containing the specific antagonistic and pathogen strains were used as controls. All combined confrontations and control strains had four replications. The linear growth of mycelia was registered during $60 \mathrm{~h}$ for both, antagonistic and pathogen every $12 \mathrm{~h}$ in dual and individual culture plates. Registration of mycelia growth stopped when mycelia in dual cultures reached contact. 
Scanning Electron Microscopy (SEM) was used to analyze and verify the antagonistic and pathogen interaction. Disc samples of $5 \mathrm{~mm}$ diameter were obtained from the mycelia contact zone of selected dual petri plates with Tk and P. capsici. Selected areas of contact were fixed in FAA (formaldehyde-acetic acid-alcohol), dehydrated with ethanol, dried with $\mathrm{CO}$ to a critical point, coated in gold and observed. Images of selected areas were obtained for visual analysis of antagonistic and pathogen interaction.

\subsection{Sporulation Tests}

Sporangia formation was induced for each dual confrontation using standard procedures for P. capsici. Four discs of $5 \mathrm{~mm}$ diameter each were obtained from the mycelia contact zone of each dual confrontation. The discs with mycelia were placed on a Petri plate, with $10 \mathrm{ml}$ of distilled water and incubated in a chamber for $48 \mathrm{~h}$ at $30^{\circ} \mathrm{C}$. A millimetric transparent grid sheet was placed on top of the discs and a $2 \times 2 \mathrm{~mm}$ area was selected and examined under the light microscope to register the number of full or empty sporangia. The same procedure was applied to induce and quantify sporangia formation in the P. capsici controls.

\section{Results}

\subsection{Phytophthora Identification}

The two pathogen isolates were identified as Phytophthora sp. based on morphological characteristics of asexual structures, and designated with the codes RDP-1 and RDP-2. Additionally to the taxonomic identification, molecular analyses were performed to confirm the species identification. The PCR products resulted in a band of $595 \mathrm{bp}$, and the sequence alignment with the NCBI database confirmed close homology (96\%) to $P$ capsici.

\subsection{Antagonism of Trichoderma Against P. capsici}

Dual culture assays showed that mycelia reached contact after $60 \mathrm{~h}$. Both $P$. capsici isolates stopped growing in presence of the three Trichoderma isolates, however, only Ta and Tk overgrew the pathogen (Figure 1). The contact zone of P. capsici (RDP-1 and RDP-2) and Th (Figure 2) only exhibited thickening of mycelia.

Mycelia of the two P. capsici strains grew significantly less at $60 \mathrm{~h}$ in presence of $\mathrm{Th}(\mathrm{p}<0.01)$ compared to the control (Table 1). Also, P. capsici RDP-1 grew significantly less at $60 \mathrm{~h}$ in presence of $\mathrm{Tk}(\mathrm{p}<0.05)$ compared to the control.

The interaction between mycelia of the antagonistic and pathogen was observed using SEM, which revealed mycoparasitism of Tk on $P$. capsici. Mycoparasitism appears in two different ways: coiling and penetration of $P$. capsici hyphae by Tk (Figure 3).

Table 1. P. capsici lineal mycelia growth $(\mathrm{mm})$ in confrontation with Trichoderma isolates every 12 hours

\begin{tabular}{lllllll}
\hline Trichoderma strain & P. capsici strain & $12 \mathrm{~h}$ & $24 \mathrm{~h}$ & $36 \mathrm{~h}$ & $48 \mathrm{~h}$ & $60 \mathrm{~h}$ \\
\hline Tk-NRRL50190 & & $4.15^{*}$ & $9.85^{* *}$ & $14.00^{*}$ & $19.63^{*}$ & $21.35^{*}$ \\
Ta-NRRL50191 & RDP1 & $4.23^{*}$ & 8.95 & 13.58 & 19.23 & 23.10 \\
Th-7 & & 3.63 & $9.53^{*}$ & 13.70 & 18.90 & $20.95^{* *}$ \\
None (Control) & & 3.33 & 8.65 & 13.25 & 18.55 & 23.05 \\
Tk-NRRL50190 & & 3.58 & 8.65 & 13.25 & 19.00 & 22.75 \\
Ta-NRRL50191 & RDP2 & 3.63 & 9.13 & 13.33 & $19.50^{*}$ & 22.65 \\
Th-7 & & 3.45 & 8.43 & 13.00 & 18.18 & $20.55^{* *}$ \\
None (Control) & & 3.20 & 9.20 & 13.53 & 18.35 & 23.85
\end{tabular}

Note. ${ }^{*}$ Indicates a significant $(\mathrm{p}<0.05)$ difference from the control mean within same column.

** Indicates a highly significant $(\mathrm{p}<0.01)$ difference from the control mean within same column. 


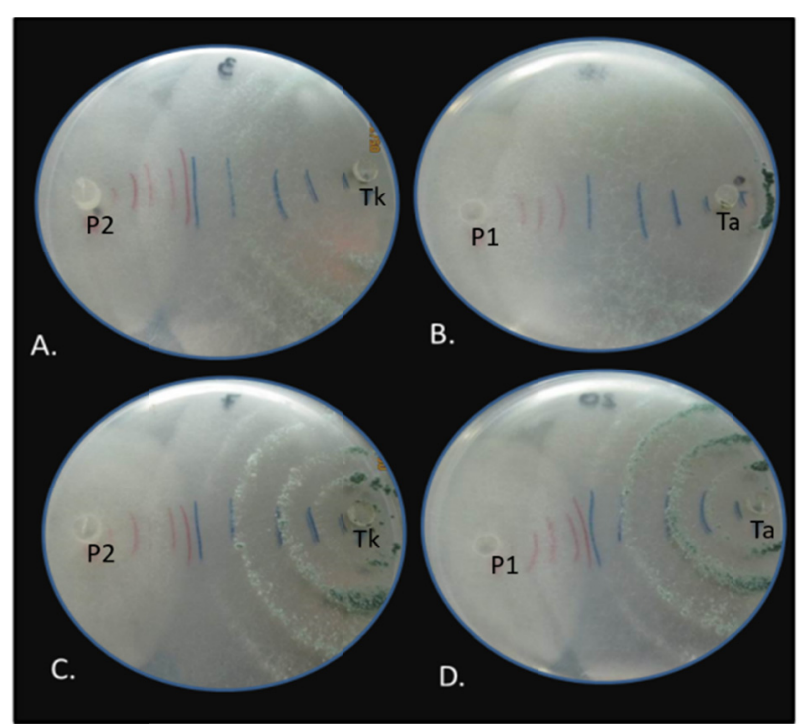

Figure 1. Overgrowth and growth inhibition of P. capsici-RDP1 (P1) and RDP2 (P2) by $T$. koningiopsis-NRRL50190 (Tk) and T. asperellum-NRRL50191 (Ta)

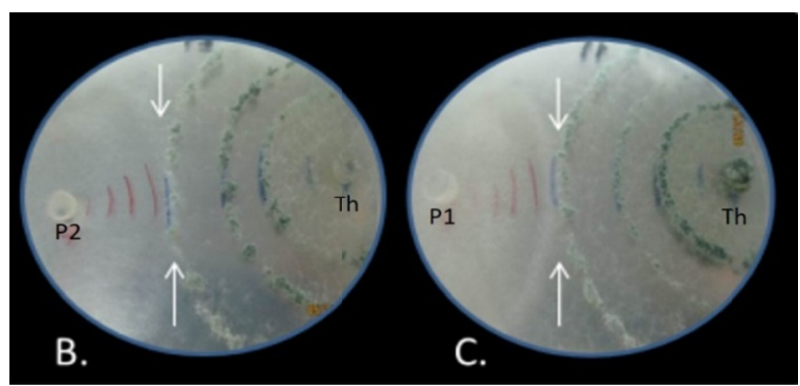

Figure 2. Dual growth of T. harzianum- Th7 and P. capsici strains RDP1 (P1) and RDP2 (P2). The arrows indicate the thickening of the mycelia at the contact zone

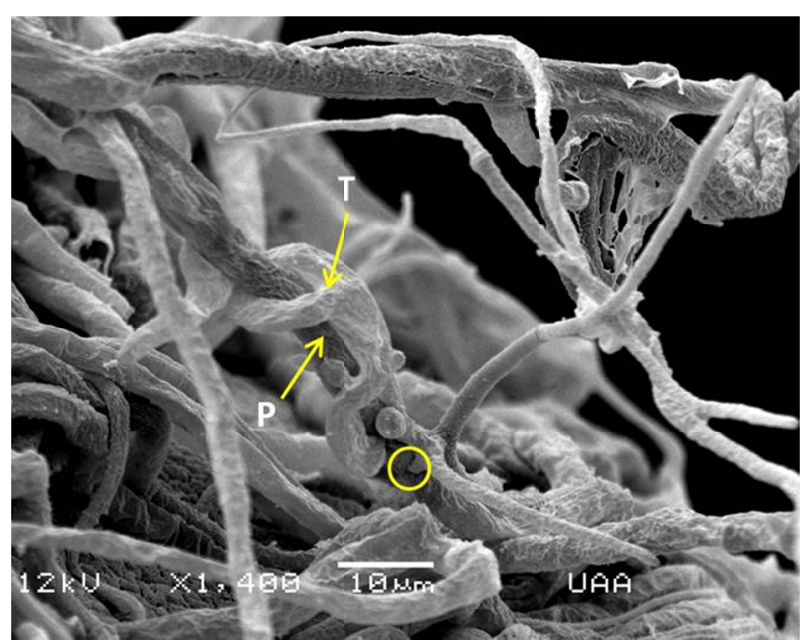

Figure 3. Mycoparasitims of T. koningiopsis (Tk NRRL50190) on P. capsici captured with a Scanning Electron Microscope. Hyphae of Tk (T) is tightly coiled around the hypha of P. capsici (P). Also, the hypha of P. capsici appears penetrated by Tk (encircled) 


\subsection{Effect of Trichoderma on P. capsici Sporangia Production}

Confrontations with Tk, Ta and Th strongly reduced sporangia production of RDP1 by $95.6,81.3$ and $78 \%$ of the control ( $\mathrm{p}<0.01$; Table 2). Similar levels of sporangia reduction were observed with strain RDP-2 of P. capsici, except for Th, which reduced sporangia by only $28.2 \%$ with no significant difference from the control $(\mathrm{p}>0.05)$. These results showed that the three strains and species of Trichoderma inhibit sporangia production of $P$. capsici under lab controlled conditions.

Microscopic observations displayed the apparent invasion of sporangia by hyphae of Tk and Ta (Figure 4). Also it is worth mention the mean difference of 60.8 sporangia per unit area $(68 \%)$ between the two strains of $P$. capsici in the absence of Trichoderma (Figure 5).

Table 2. Inhibition effect of Trichoderma strains on P. capsici sporangia production

\begin{tabular}{llll}
\hline Trichoderma strain & P. capsici strain & No. sporangia & Sporangia inhibition \\
\hline Tk-NRRL50190 & & $5.6^{* *}$ & $95.6 \%$ \\
Ta-NRRL50191 & RDP1 & $23.6^{* *}$ & $81.3 \%$ \\
Th-7 & & $27.6^{* *}$ & $78.0 \%$ \\
Control & 125.8 & $0 \%$ \\
\hline Tk-NRRL50190 & $15.6^{* *}$ & $76.0 \%$ \\
Ta-NRRL50191 & $9.5 * *$ & $85.4 \%$ \\
Th-7 & RDP2 & $46.7 \mathrm{~ns}$ & $28.2 \%$ \\
Control & & 65.0 & $0 \%$ \\
\hline
\end{tabular}

Note. The values in the table are the average of four replicates.

* Significant $(\mathrm{P} \leq 0.05)$, and ** highly significant $(\mathrm{P} \leq 0.01)$ difference from the control.

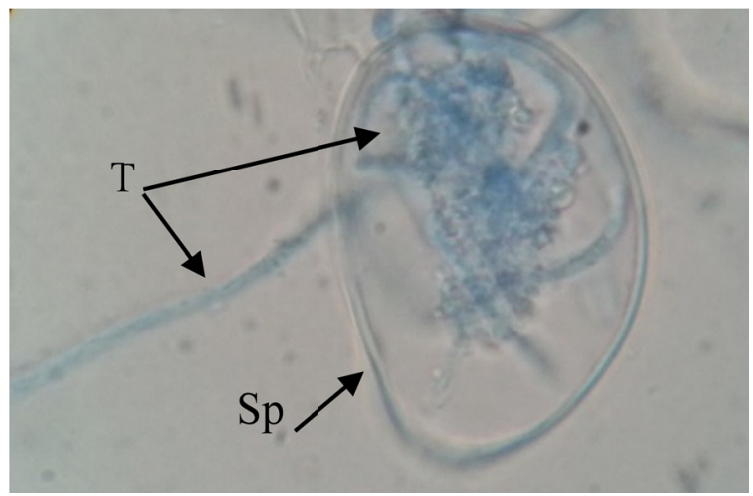

Figure 4. Hyphae of Tk NRRL50190 (T) invading a P. capsici sporangium (Sp)

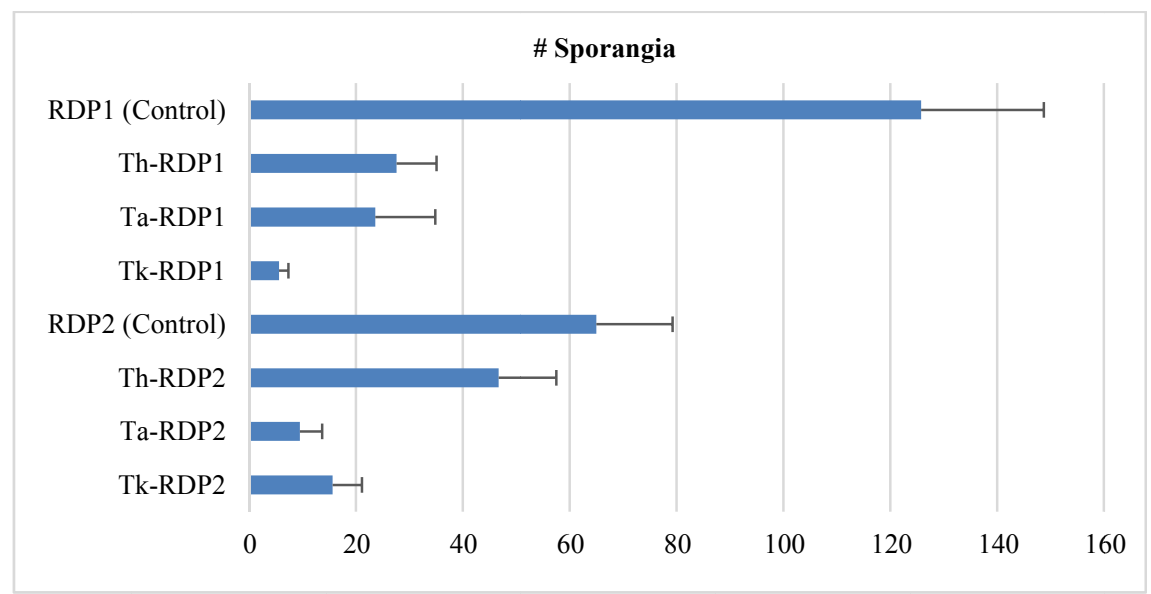

Figure 5. Mean sporangia countings (in $2 \mathrm{~mm}^{2}$ ) of P. capsici strains (RDP1 and RDP2) in presence of three species of Trichoderma (Tk, Ta and Th). Bars denote standard errors of the mean 


\section{Discussion}

When using a Trichoderma isolate as a biological control agent it is important to consider its ability to inhibit the growth and development of the target pathogen. According to the results obtained in this study, different species of Trichoderma are capable to halt the mycelial growth of P. capsici. T. harzianum (Th-7), showed certain ability that may be associated to fungistatic effects, while T. koningiopsis (Tk NRRL50190) and T. asperellum (Ta NRRL50191) showed some fungicidal effects that were captured when hyphae and sporangia of the pathogen were parasitized by $\mathrm{Tk}$ and Ta hyphae. Similar results have been reported for T. koningiopsis against Macrophomina phaseolina (Hernández-Mendoza et al., 2015). Osorio-Hernández et al. (2011) also reported 31 Mexican Trichoderma isolates with the ability to produce volatile compounds with inhibitory properties against P. capsici. Therefore biocontrol effects of Trichoderma might be due to direct interactions with the pathogen, such as in mycoparasitism, which involves the synthesis of certain compounds acting as antibiotics (Benítez et al., 2004). However, in this work we did not attempt to evaluate the microbial production of specific compounds.

To the authors' knowledge, the effect of Trichoderma sp. on sporangia production of $P$. capsici has not been documented. Some have focused on the possible inhibition of zoospore production (Ayobi et al., 2010), and germination of P. capsici (Segarra et al., 2013) by Trichoderma. Because different forms of inoculum (mycelia, sporangia, zoospores, oospores) may contribute to the spread of $P$. capsici, accurate detection and quantification of these propagules is essential for disease prevention and management (Larkin et al., 1995). Considering our results, the three antagonistic species and isolates: Tk NRRL50190, Ta NRRL50191, and Th-7 are able to inhibit mycelia growth and sporangia production of $P$. capsici, therefore the three species have the potential to directly or indirectly reduce different sources of primary inoculum - such as mycelia, sporangia and zoospores, and thus the probability of infection (Granke \& Hausbeck, 2010). Zoosporogenesis depends on mature sporangia (Maltese et al., 1995), which live longer than the short lived water motile zoospores (Segarra et al., 2013).

\section{Conclusion}

Molecular studies of DNA confirmed and complemented the morphological identification of two strains of $P$. capsici that were isolated in 2015 from commercial cultivated pepper roots in Aguascalientes, Mexico. The three Trichoderma isolates showed promising applications for biological control of P. capsici. T. koningiopsis (Tk NRRL50190) and T. asperellum (Ta NRRL50191) showed fungicidal activity, while T. harzianum (Th-7) only showed fungistatic activity. Given the different antagonistic effects on P. capsici by Trichoiderma species, further studies should be conducted to examine, for example, possible synergistic effects among Trichoderma species.

\section{Acknowledgements}

To CONACYT-Mexico for providing the graduate scholarship No. 286770 for Estefania Ramirez-Delgado in the Master's Program of Agronomic Sciences, Universidad Autónoma de Aguascalientes.

\section{References}

Ayobi, N., Zafari, D., \& Mirabolfathi, M. (2010). Effect of Trichoderma species on zoospore production of Phytophthora sojae, disease severity, and glucanase enzymes. Iran. J. Plant Path., 46(3), 57-59. Retrieved from https://www.cabdirect.org/cabdirect/abstract/20133240504

Bae, S., Mohanta, T., Chung, J., Ryu, M., Park, G., Shim, S., ... Bae, H. (2016). Trichoderma metabolites as biological control agents against Phytophthora pathogens. Biological Control, 92, 128-138. https://doi.org/ 10.1016/j.biocontrol.2015.10.005

Bailey, B. A., \& Lumsden, R. R. (1998). Direct effect of Trichoderma and Gliocladium on plant growth and resistance to pathogens. In C. O. Kubicek, G. E. Harman, \& K. L. Ondik (Eds.), Trichoderma and Gliocadium: Enzymes, Biological Control and Commercial Applications. Taylor and Francis, London. Retrieved from http://www.sid.ir/En/Journal/ViewPaper.aspx?ID=216905

Benítez, T., Rincón, A. M., Limón, M. C., \& Codón, A. C. (2004). Biocontrol mechanisms of Trichoderma strains. International Microbiology, 7(4), 249-260. Retrieved from http://scielo.isciii.es/pdf/im/v7n4/ Benitez.pdf

Chemeltorit, P. P., \& Mutaqin, K. H. (2016). Combining Trichoderma hamatum THSW13 and Pseudomonas aeruginosa BJ10-86: A synergistic chili pepper seed treatment for Phytophthora capsici infested soil. European Journal of Plant Pathology, 2016, 1-10. https://doi.org/10.1007/s10658-016-0988-5

Erwin, D. C., \& Ribeiro, O. K. (1996). Phytophthora Diseases Worldwide. American Phytopathological Society Press, St. Paul, MN. 
Fernández-Herrera, E., Acosta-Ramos, M., Ponce-González, F., \& Manuel-Pinto, V. (2007). Manejo Biológico de Phytophthora capsici Leo., Fusarium oxysporum Schlechtend. iFr. y Rhizoctonia solani Kühn en Jitomate (Lycopersicon esculentum Mili.). Revista Mexicana de Fitopatología, 25(1), 35-42. Retrieved from http://www.scielo.org.mx/scielo.php?script=sci_arttext\&pid=S0185-33092007000100005

Fernández-Pavía, S. P., Biles, C. L., Waugh, M., Onsurez-Waugh, K., Rodríguez-Alvarado, G., \& Liddell, C. (2004). Characterization of Southern New Mexico Phytophthora capsici Leonian Isolates from Pepper (Capsicum annuum L). Revista Mexicana De Fitopatología, 22(1), 82-89. Retrieved from http://www. redalyc.org/html/612/61222111

Foster, J. M., \& Hausbeck, M. K. (2010). Managing Phytophthora Crown and Root Rot in Bell Pepper Using Fungicides and Host Resistance. Plant Disease, 94(6), 697-702. https://doi.org/10.1094/PDIS-94-6-0697

Granke, L. L., \& Hausbeck, M. K. (2010). Effects of Temperature, Concentration, Age, and Algaecides on Phytophthora capsici Zoospore Infectivity. Plant Disease, 94(1), 54-60. https://doi.org/10.1094/PDIS-94$1-0054$

Granke, L. L., Quesada-Ocampo, L., \& Hausbeck, M. K. (2012). Advances in Research on Phytophthora capsici on Vegetable Crops in The United States. Plant Disease, 95(11), 1588-1600. https://doi.org/10.1094/ PDIS-02-12-0211-FE

Harman, G. E. (2000). Myths and Dogmas of Biocontrol. Plant Disease, 8, 377-393. https://doi.org/10.1094/ PDIS.2000.84.4.377

Hernández-Mendoza, J. L., Sánchez-Pérez, M. I., González-Prieto, J. M., Quiroz-Velásquez, J. D., García-Olivares, J. G., \& Gill-Langarica, H. R. (2015). Antibiosis of Trichoderma spp. strains native to northeastern Mexico against the pathogenic fungus Macrophomina phaseolina. Brazilian Journal of Microbiology, 46(4), 1093-1101. https://doi.org/10.1590/S1517-838246420120177

Jiang, H., Zhang, L., Zhang, J.-Z., Ojaghian, M. R., \& Hyde, K. D. (2016). Antagonistic interaction between Trichoderma asperellum and Phytophthora capsici in vitro. Journal of Zhejiang University: Science B, 17(4), 271-281. https://doi.org/10.1631/jzus.B1500243

Jong-Hiu, L., \& Sang-Dal, K. (2010). Biocontrol of Phytophthora Blight of Red Pepper Caused by Phytophthora capsici Using Bacillus subtilis AH18 and B. licheniformis K11 Formulations. Journal of the Korean Society for Applied Biological Chemistry, 53(6), 766-773. https://doi.org/10.3839/jksabc.2010.116

Larkin, R. P., Ristaino, J. B., \& Campbell, C. L. (1995). Detection and Quantification of Phytophthora capsici in Soil. Phytopathologia Mediterranea, 85(10), 1057-1063. https://doi.org/10.1094/Phyto-85-1057

Maltese, C. E., Conigliaro, G., \& Shaw, D. S. (1995). The development of sporangia of Phytophthora infestans. Mycol. Res., 99(10), 1175-1181. https://doi.org/10.1016/S0953-7562(09)80273-6

Marín, F., Diánez, F., Santos, M., Carretero, F., Gea, F. J., Casta-eda, C., ... Yau, J. A. (2014). Control of Phytophthora capsici and Phytophthora parasitica on pepper (Capsicum annuum L.) with compost teas from different sources, and their effects on plant growth promotion. Phytopathologia Mediterranea, 53(2), 216-228. https://doi.org/10.14601/Phytopathol_Mediterr-12173

Osorio-Hernández, E., Hernández-Castillo, F. D., Gallegos-Morales, G., Rodríguez-Herrera, R., \& Castillo-Reyes, F. (2011). In-vitro behavior of Trichoderma spp. against Phytophthora capsici Leonian. African Journal of Agricultural Research, 6(19), 4594-4600. Retrieved from http://www.academicjournals. org/journal/AJAR/article-stat/8D7DEF138514

Pérez-Moreno, L., Durán-Ortiz, L. J., Ramírez-Malagón, R., Sánchez-Palé, J. R., \& Olalde-Portugal, V. (2003). Compatibilidad Fisiológica y Sensibilidad a Fungicidas de Aislamientos de Phytophthora capsici Leo. Revista Mexicana de Fitopatología, 21(1), 19-25. Retrieved from http://www.redalyc.org/html/612/ 61221103

Phuwapraisirisan, P., Rangsan, J., Siripong, P., \& Tip-Pyang, S. (2006). 9-epi-Viridiol, a novel cytotoxic furanosteroid from soil fungus Trichoderma virens. Natural Product Research, 20(14), 1321-1325. https://doi.org/10.1080/14786410601101969

Quesada-Ocampo, L. M., \& Hausbeck, M. K. (2010). Resistance in tomato and wild relatives to crown and root rot caused by Phytophthora capsici. Phytopathology, 100(6), 619-627. https://oi.org/10.1094/PHYTO100-6-0619 
Raeder, U., \& Broda, P. (1985), Rapid preparation of DNA from filamentous fungi. Letters in Applied Microbiology, 1, 17-20. https://doi.org/10.1111/j.1472-765X.1985.tb01479.x

Robles-Yerena, L., Rodríguez-Villarreal, R. A., Ortega-Amaro, M. A., Fraire-Velázquez, S., Simpson, J., Rodríguez-Guerra, R., \& Jiménez-Bremont, J. F. (2010). Characterization of a new fungal antagonist of Phytophthora capsici. Scientia Horticulturae, 125(3), 248-255. https://doi.org/10.1016/j.scienta.2010. 03.016

Segarra, G., Avilés, M., Casanova, E., Borrero, C., \& Trillas, I. (2013). Effectiveness of biological control of Phytophthora capsici in pepper by Trichoderma asperellum strain T34. Phytopathologia Mediterranea, 52(1), 77-83. Retrieved from https://idus.us.es/xmlui/handle/11441/30458

Silva-Rojas, H. V., Fernández-Pavía, S. P., Góngora-Canul, C., Macías-López, B. C., \& Ávila-Quezada, G. D. (2009). Distribución espacio temporal de la marchitez del chile (Capsicum annuum L.) en Chihuahua $\mathrm{e}$ identificación del agente causal Phytophthora capsici Leo. Revista Mexicana de Fitopatologia, 27(2), 134-147. Retrieved from http://www.scielo.org.mx/scielo.php?pid=S0185-33092009000200006\&script= sci_arttext\&tlng=pt

\section{Copyrights}

Copyright for this article is retained by the author(s), with first publication rights granted to the journal.

This is an open-access article distributed under the terms and conditions of the Creative Commons Attribution license (http://creativecommons.org/licenses/by/4.0/). 